\title{
Effects of housing conditions and glutamine levels on growth performance of post-weaning piglets
}

\section{Efeitos da condição de alojamento e do nível de glutamina sobre o desempenho de leitões desmamados}

\author{
Arturo Pardo Lozano ${ }^{1}$; Angela Rocio Poveda-Parra ${ }^{2 *}$; Eduardo Raele \\ Aliny Kétilim Novais ${ }^{3}$; Roberta Abrami Monteiro da Silva ${ }^{1}$; \\ Graziela Drociunas Pacheco; ${ }^{1}$ David Gavioli'; Danyel Bueno Dalto ${ }^{3}$; \\ Caio Abércio da Silva ${ }^{5}$
}

\begin{abstract}
This study aimed to determine the effects of housing conditions and glutamine (GLN) levels on growth performance and incidence of diarrhea in weaned piglets. Forty-eight piglets were randomly assigned ( $4 \times 2$ factorial design) to one of the eight experimental diets represented by four levels of dietary GLN $(0.0,1.0,1.5$ or $2.0 \%)$ and two housing conditions $(\mathrm{AD}=$ adequate and INAD = inadequate). From 22 to 28 days of age all animals were challenged daily with Escherichia coli polysaccharides. No effect of GLN level was found on daily gain (ADG), daily feed intake (ADFI) or body weight at 28 days postweaning (BW28). For housing conditions, ADG at 21 days after weaning was greater for animals of treatment $\mathrm{AD}$ than INAD, and $\mathrm{AD}$ had lower body weight variation than INAD pigs at 21 days after weaning. Considering the whole period, AD had a higher ADG, ADFI and BW28 than INAD. However, an interaction effect was observed for feed:gain rate, in which values decreased linearly $(\mathrm{Y}=2.1727$ - 0.4017x; $\mathrm{R}^{2}=0.92$ ) just for AD pigs as GLN levels increased. No GLN level effects were observed for diarrhea incidence; however, AD had a higher number of animals without diarrhea and with lower incidence of severe diarrhea than INAD pigs. In conclusion, supplementing GLN doesn't affect ADG, ADFI or BW28 but it improves feed efficiency when housing conditions are adequate.
\end{abstract}

Key words: Amino acid. Housing condition. Lps. Pigs. Weanling.

\section{Resumo}

Este estudo visou determinar o efeito das condições de alojamento e dos níveis de glutamina (GLN) sobre o desempenho e a incidência de diarréia em leitões desmamados. Quarenta e oito leitões foram divididos aleatoriamente (modelo fatorial $4 \times 2$ ) e submetidos a oito dietas experimentais representadas por quatro níveis de GLN dietética $(0.0,1.0,1.5$ ou $2.0 \%)$ e duas condições de alojamento $(\mathrm{AD}=$ adequada e INAD = inadequada). A partir do $22^{\circ}$ dia de idade até os 28 dias de experimentação, todos os leitões foram desafiados com lipopolissacarídeo de Escherichia coli. Nenhum efeito do nível de

\footnotetext{
${ }^{1}$ Drs. em Ciência Animal, Universidade Estadual de Londrina, UEL, Londrina, PR, Brasil. Bolsistas do Programa PEC/PG/ CAPES. E-mail: setarturo@hotmail.com; ro_abrami@hotmail.com; grazivetuel@yahoo.com.br

2 Pós-Doutoranda em Ciência Animal, UEL, Londrina, PR, Brasil. E-mail: angelapovedaparra@hotmail.com

3 Discentes do Curso de Doutorado em Ciência Animal, UEL, Londrina, PR, Brasil. E-mail: duraele@yahoo.com.br; alinynovais@, hotmail.com; danyelbd@hotmail.com

${ }^{4}$ M.e em Ciência Animal, UEL, Londrina, PR, Brasil. E-mail: davidgavioli@hotmail.com

${ }_{5}$ Prof. Dr. Associado, Departamento de Zootecnia, UEL, PR, Brasil. E-mail: casilva@uel.br

* Author for correspondence
} 
GLN foi observado sobre o ganho de peso diário (GDP) consumo diário de ração (CDR), conversão alimentar (CA), e peso dos animais no dia 28 pós-desmame (BW28). Para a condição de alojamento, o valor de GDP no dia 21 pós-desmame foi maior para os animais AD que os INAD e os animais AD apresentaram menor heterogeneidade de peso que INAD. Considerando todo o período experimental, os animais de AD obtiveram maiores GDP, CDR e BW28 que animais INAD. No entanto, houve efeito de interação para $C A$, com valores decrescendo linearmente $\left(Y=2,17270,4017 \mathbf{x} ; R^{2}=0.92\right)$ para leitões AD conforme aumentou a suplementação de GLN. Nenhum efeito de nível de GLN foi observado para a incidência de diarreia, no entanto, o tratamento $\mathrm{AD}$ apresentou maior número de animais sem diarreia e menor número de diarreias severas. Em conclusão, a suplementação com GLN não afeta GDP, CDR e BW28, mas melhora a eficiência alimentar quando as condições de alojamento são favoráveis.

Palavras-chave: Aminoácido. Condição de alojamento. Desmame. Leitões. LPS.

\section{Introduction}

Currently in Brazil there are no standardized housing systems for weaned pigs, and therefore, a big range of different facilities are observed in pig farms. Although some studies have evaluated individual risk factors related to health status and growth performance (MORES et al., 1998; DALLA COSTA et al., 2000), studies regarding the evaluation of risk factors in housing conditions and their interaction with functional nutritional supplements, such as glutamine (GLN), are even less common or non-existent.

High numbers of risk factors in housing systems impair growth performance, decrease group uniformity, and increase the incidence of diseases, such as diarrhea. Actually, diarrhea is one of the diseases most related to environmental risk factors and management after weaning, and it is generally caused by infections with enterotoxigenic Escherichia coli (SILVA et al., 1999).

Under adverse immunologic conditions, such as infections, the systemic demand for GLN is higher than its absorption/synthesis rate, and consequently, it becomes a conditionally essential substance for the animals (WU et al., 2011). Considering the important and unique metabolic functions performed by this amino acid, its supplementation for weaned pigs appears to be a promising alternative to counteract or alleviate intestinal disorders and improve performance. In fact, diets supplemented with $2 \%$ GLN had beneficial effects in alleviating growth depression in E. coli-challenged early-weaned pigs (YI et al., 2005).

Given that the effects of GLN in the first days after weaning are well known, this study aimed to evaluate the effects of different dietary GLN levels on growth performance and incidence of diarrhea later in the nursery phase of pigs subjected to two different housing conditions.

\section{Material and Methods}

\section{Animals and treatments}

Experimental procedures were approved by the Committee on Ethics in Animal Use (CEUA), protocol number 15.185.2011.74 of the Universidade Estadual de Londrina.

Forty-eight Agroceres-PenArlan piglets, 24 castrated males and 24 females, were selected at weaning with $6.16 \pm 0.78 \mathrm{~kg}$ body weight (BW) and $21 \pm 2$ days of age. Immediately after weaning, piglets were randomly housed by pairs (one castrated male and one female; according to their BW) in nursery facilities with one of two different housing conditions: adequate, $\mathrm{AD})$ slatted plastic flooring pens $\left(0.7 \mathrm{~m}^{2}\right.$ per pig), equipped with linear feeders (0.15 $\mathrm{cm}$ per animal) and adjustable nipple drinkers with a flow rate of $0.95 \mathrm{~L} \mathrm{~min}^{-1}$; and inadequate, INAD) solid concrete flooring pens $\left(1.4 \mathrm{~m}^{2}\right.$ per pig) half covered with wood shavings, equipped with wooden linear feeders $(0.15 \mathrm{~cm}$ per animal $)$ during the first 14 days of the experiment and, thereafter, semi-automatic metal feeders $(0.30 \mathrm{~cm}$ per animal $)$ 
and non-adjustable $90^{\circ}$ angle nipple drinkers placed at $37.5 \mathrm{~cm}$ high with a flow rate of $1.8 \mathrm{~L} \mathrm{~min}^{-1}$.

For both housing conditions, curtains were used to control room temperature and infrared lamps provided additional heating. Additionally, all piglets were randomly assigned (according to their BW) to one of the four experimental diets: GLN-0) basal prestarter and starter diets without L-GLN (Ajinomoto Brazil) (Table 1); GLN-1) basal pre-starter and starter diets supplemented with 1.0\% of L-GLN; GLN-1.5) basal pre-starter and starter diets supplemented with $1.5 \%$ of L-GLN; and GLN-2) basal pre-starter and starter diets supplemented with $2.0 \%$ of L-GLN. Diets were initially formulated without GLN and after preparation, the different levels of GLN were added. The basal iso-nutrient experimental diets (Table 1) exceeded the recommended levels for all other nutrients (ROSTAGNO et al., 2011).

Table 1. Composition of the basal diet (as feed basis).

\begin{tabular}{lcc}
\hline \multicolumn{1}{c}{ Ingredient, \% } & $\begin{array}{c}\text { Pre-starter 1 } \\
(1-14 \text { d post-weaning })\end{array}$ & $\begin{array}{c}\text { Starter 2 } \\
\text { (15-28 d post-weaning) }\end{array}$ \\
\hline Corn & 53.25 & 67.77 \\
Soybean meal 45\% & 23.73 & 20.88 \\
Dried skim milk & 10.00 & 04.00 \\
Soybean oil & 03.79 & 00.23 \\
Sugar & 03.00 & 02.00 \\
Dried whey & 02.00 & 02.00 \\
Dicalcium phosphate & 01.66 & 01.36 \\
Limestone & 00.64 & 00.70 \\
Salt & 00.51 & 00.36 \\
L-lysine HCL & 00.63 & 0.34 \\
DL-methionine & 00.24 & 00.05 \\
L-threonine & 00.30 & 0.10 \\
L-tryptophan & 00.05 & 00.01 \\
Mineral and vitamin premix & 3 & 00.20 \\
Total & 00.20 & 100 \\
\hline
\end{tabular}

${ }^{1}$ The calculated compositions for metabolizable energy, crude protein, lysine, arginine, $\mathrm{Ca}$, and $\mathrm{P}$ of the basal pre-starter diet were $3,400 \mathrm{kcal} \mathrm{kg}^{-1}, 20.0 \%, 1.5 \%, 0.97 \%, 0.85 \%$ and $0.5 \%$, respectively.

${ }^{2}$ The calculated compositions for metabolizable energy, crude protein, lysine, arginine, $\mathrm{Ca}$, and $\mathrm{P}$ of the basal starter diet were 3,230 $\mathrm{kcal} \mathrm{kg}^{-1}, 17.4 \%, 1.0 \%, 0.96 \%, 0.72 \%$ and $0.4 \%$, respectively.

${ }^{3}$ Provided per kilogram of diet: vitamin A, 18,000 UI; vitamin $\mathrm{D}_{3}, 3,600 \mathrm{UI}$; vitamin E, 40 UI; vitamin K, $3.6 \mathrm{mg}$; vitamin $\mathrm{B}_{1}, 2.8$ mg; vitamin $\mathrm{B}_{6}, 3 \mathrm{mg}$; vitamin $\mathrm{B}_{12}, 36 \mu \mathrm{g}$; niacin, $60 \mathrm{mg}$; pantothenic acid, $32 \mathrm{mg}$; biotin, $200 \mu \mathrm{g}$; folic acid, $8 \mathrm{mg}$; Fe as ferrous sulfate, $200 \mathrm{mg}$; $\mathrm{Cu}$ as copper sulfate, $50 \mathrm{mg}$; $\mathrm{Mn}$ as manganese oxide, $11 \mathrm{mg}$; $\mathrm{Zn}$ as zinc oxide, $180 \mathrm{mg}$; I as calcium iodate, $2.0 \mathrm{mg}$.

Regardless of the experimental housing conditions or GLN level, from 22 to 28 days of age post-weaning, all piglets were challenged daily with E. coli polysaccharides (LPS; serotype 0111: B4 L2630, Sigma Aldrich), at $0.3 \mu \mathrm{g}$ per animal as described by Parra et al. (2013). During the 28-day experimental period (weaning $=$ day 0 ), all animals were fed ad libitum.

\section{Data collection}

To define housing conditions (AD vs INAD), the protocols described by Mores et al. (1998) and Dalla Costa et al. (2000) were applied considering feeder space per pig (FSP), drinker height (DH), drinker maximum flow rate (MFR) and floor type to determine the quality of the facilities. The evaluation of diarrhea was performed according to Madec and 
Josse (1983). Average daily feed intake (ADFI), average daily gain (ADG), and body weight were recorded at the beginning and end of the experimental period and feed:gain rate (FCR) was calculated. Facility temperatures were recorded daily.

\section{Statistical analysis}

Data were analyzed using the ExpDes package of $\mathrm{R}$ statistical program (FERREIRA et al., 2011) according to a randomized arrangement of treatments in blocks with the eight treatments as the main independent variables. The pen with two pigs was considered the experimental unit. The residual error term was used to test the treatment effects. To assess the incidence and intensity of diarrhea, the chi-square test was applied. Differences were considered significant at $\mathrm{P} \leq 0.05$ and tendencies at $0.05<\mathrm{P} \leq 0.10$. All results are expressed as adjusted means \pm SEM.

\section{Results and Discussion}

Initial BW was not different among treatments $(6.17 \pm 0.78 \mathrm{~kg})$ and temperature variations were similar for both housing conditions (between $22.6 \pm$ $0.8^{\circ} \mathrm{C}$ and $30.7 \pm 1.3{ }^{\circ} \mathrm{C}$ ).
No effect of GLN level ( $\mathrm{P}>0.05$; Table 2) was found on ADG, ADFI or body weight at day 28 post-weaning (BW28). These results are in line with another study (YI et al., 2005), in which there was no effect of treatment throughout the overall experimental period. In contrast to our findings, some studies demonstrated that dietary supplementation with GLN or glycyl-GLN dipeptide improved growth performance in the first week after weaning in piglets challenged with E. coli $\mathrm{K} 88+$ or LPS (YI et al., 2005; JIANG et al., 2009). These results suggest that at an older age (28 days post-weaning) these effects might be overshadowed by normal physiologic growth. However, it is noteworthy to mention that the level of $0.3 \mu \mathrm{g}$ of LPS used in the present experiment is much lower than the level used by other authors e.g. $200 \mu \mathrm{g} \mathrm{kg}^{-1}$ body weight of LPS in Jiang et al (2009). In a previous study, Lozano et al. (2014) showed that challenging weaned pigs with $0.3 \mu \mathrm{g}$ of LPS per pig per day did not promote any moderate or transient cortisol alterations. According to García-Herrera et al. (2008), increased cortisol values are expected in LPS challenged animals due to the effects of endotoxemia. Therefore, it is reasonable to consider that the present level of LPS was not enough to promote physiologic stress and alter GLN metabolism.

Table 2. Growth performance of piglets at 28 days after weaning according to dietary glutamine level and housing condition.

\begin{tabular}{|c|c|c|c|c|c|c|c|}
\hline & \multirow{2}{*}{ Housing condition } & \multicolumn{4}{|c|}{ Glutamine level (\%) } & \multirow{2}{*}{ Average } & \multirow{2}{*}{ SEM } \\
\hline & & 0 & 1.0 & 1.5 & 2.0 & & \\
\hline \multirow{2}{*}{$\mathrm{ADG}, \mathrm{kg}$} & $\mathrm{AD}$ & 0.20 & 0.26 & 0.27 & 0.23 & $0.23^{a}$ & 0.12 \\
\hline & INAD & 0.17 & 0.15 & 0.18 & 0.16 & $0.16^{\mathrm{b}}$ & 0.14 \\
\hline \multirow{2}{*}{ ADFI, kg } & $\mathrm{AD}$ & 0.38 & 0.41 & 0.31 & 0.37 & $0.37^{\mathrm{a}}$ & 0.11 \\
\hline & INAD & 0.32 & 0.33 & 0.29 & 0.31 & $0.31^{\mathrm{b}}$ & 0.12 \\
\hline \multirow{2}{*}{$\mathrm{F}: \mathrm{G}$} & $\mathrm{AD}^{1}$ & 2.24 & 1.61 & 1.59 & 1.42 & 1.72 & 0.52 \\
\hline & INAD & 1.89 & 2.25 & 1.88 & 2.01 & 2.01 & 0.53 \\
\hline \multirow{2}{*}{ BW28,kg } & $\mathrm{AD}$ & 11.39 & 13.41 & 13.46 & 12.07 & $12.58^{\mathrm{a}}$ & 2.25 \\
\hline & INAD & 11.12 & 10.54 & 11.52 & 10.23 & $10.85^{b}$ & 2.65 \\
\hline
\end{tabular}

Housing condition adequate $=\mathrm{AD}$; housing condition inadequate $=\mathrm{INAD} ; \mathrm{ADG}=$ average daily gain; $\mathrm{ADFI}=$ average daily feed intake; $\mathrm{F}: \mathrm{G}=$ feed:gain rate; $\mathrm{BW} 28=$ body weight at day 28 post-weaning; $\mathrm{AD}=$ adequate housing condition; $\mathrm{INAD}=$ inadequate housing condition

${ }^{\mathrm{a}, \mathrm{b}}$ Different superscript letters within a column indicate a significantly different effect $(\mathrm{P}<0.05)$

$\left.{ }^{1} \mathrm{Y}=2.1727-0.4017 \mathrm{x} ; \mathrm{R}^{2}=0.92\right)$. 
According to $\mathrm{Wu}$ et al. (2011), a large dosage of GLN (e.g. $2 \%$ GLN in the corn and soybean meal-based diet for weanling piglets) may impair growth performance. The present study showed that GLN supplementation at $2.0 \%$ of the diet for pigs during the 28 days post-weaning did not promote any negative effects on growth performance.

For housing condition, before challenging the pigs with LPS, the ADG at 21 days after weaning (ADG21) was greater for AD than INAD animals (228 g vs 160 g, respectively; $\mathrm{P}<0.05$ ). Additionally, $\mathrm{AD}$ animals had lower $\mathrm{BW}$ variation at 21 days after weaning (BW21-CV) than INAD pigs (13.4\% vs $18.6 \%$, respectively; $\mathrm{P}<0.05)$. According to Mores et al. (1998), the ADG21 and BW21-CV are useful information to evaluate the effects of risk factors affecting the growth performance of weaned pigs. Therefore, the present results indicate that the set of factors comprising the $\mathrm{AD}$ facilities were adequate and beneficial to support growth of piglets until 28 days post-weaning. Although differences were found for BW21-CV between both housing conditions, according to Mores et al. (1998), this variation remained within the normal range for this category.

Considering the whole experimental period, $\mathrm{AD}$ had higher $(\mathrm{P}<0.05)$ ADG, ADFI and BW28 than INAD animals (Table 2). The area of $0.16 \mathrm{~m}^{2}$ per piglet is adequate until $12.2 \mathrm{~kg} \mathrm{BW}$ (STOJANAC et al., 2014); therefore, it is unlikely that the area per piglet $\left(0.7\right.$ and $1.4 \mathrm{~m}^{2}$ for $\mathrm{AD}$ and INAD, respectively) disturbed growth performance in the present study. Additionally, for both housing conditions, the feeder space per pig of $0.15 \mathrm{~cm}$ was adequate to maximize feed intake (MORES et al., 1998). However, the substitution of the feeder after 14 days for INAD facilities may have influenced growth performance because those animals had to readapt to the new feeder, leading to low feed intake during the first day. Another important factor to be addressed is drinker height. For AD facilities, drinkers were adjustable and able to be positioned at $5 \mathrm{~cm}$ above the animal's back. According Dybkjaer et al. (2006), this positioning reduces the time for the piglets to establish adequate water intake. In contrast, for INAD facilities, drinkers were fixed at a $90^{\circ}$ angle and $37.5 \mathrm{~cm}$ in height above the floor, impairing water intake (DALLA COSTA et al., 2000). According to Dybkjaer et al. (2006), feed intake after weaning is related to water intake, and thus, the adequate drinker position for the AD facility may have facilitated water intake and consequently may have impacted growth performance. Also, Dalla Costa et al. (2000) showed that a maximum flow rate of $1.0 \mathrm{~L} \mathrm{~min}^{-1}$ improves water intake after weaning. In this regard, the maximum flow rate from INAD facilities was $80 \%$ higher than the recommendation and might have impaired water intake and consequently growth performance.

An effect of the interaction $(\mathrm{P}<0.05)$ between GLN levels and housing condition (Table 2) was observed for feed:gain rate $(F: G)$, in which values linearly decreased $\left(\mathrm{Y}=2.1727-0.4017 \mathrm{x} ; \mathrm{R}^{2}=\right.$ 0.92) for AD pigs as GLN supplementation levels increased, but not for INAD animals. Indeed, compared to AD-unsupplemented pigs (GLN-0) and AD supplemented with $2.0 \%$ GLN (GLN-2) there was improvement of the F:G by $36.6 \%$. The animals of nursery $\mathrm{I}$, that received feed supplemented with $1.0 \%$ GLN, showed better feed conversion when compared to nursery II (1.61 vs. 2.25 , respectively) (Table 2). The animals of nursery I that received feed with $2 \%$ GLN presented a difference in F:G when compared to animals of nursery II (1.42 vs $2.01)$. The increase in supplementation from $1 \%$ to $2 \%$ GLN resulted in improvement by $11.7 \%$ for $F: G$ (i.e. $190 \mathrm{~g}$ fewer feed per $1 \mathrm{~kg}$ of live weight gain).

This result is in line with a previous study (LOZANO et al., 2014) in which dietary supplementation with $2 \%$ GLN improved FCR of weaned pigs challenged with LPS. The positive effect of GLN in alleviating mucosal villi atrophy in animals challenged with LPS and increasing absorption of dietary nutrients (CABRERA et al., 2013) might have been potentiated by the adequate housing conditions of $\mathrm{AD}$ facilities. 
For the final weight, nursery II presented the best gain indexes for weight and feed intake (Table 2), confirming its improved environmental quality and its effect on performance parameters.

However, for all these parameters, it is possible that the higher incidence of severe diarrhea in INAD animals may have impaired their performance. No GLN level effect was observed for incidence of diarrhea $(\mathrm{P}>0.05)$. It is well known that LPS-challenged piglets provide a suitable animal model to study the effects of dietary supplementation on the incidence of diarrhea. Although metabolic changes could be involved with the development of post-weaning diarrhea after a $0.3 \mu \mathrm{g}$ LPS challenge, as reported by Parra et al. (2013), Lozano et al. (2014) did not observe any major physiologic alteration in weaned pigs challenged with $0.3 \mu \mathrm{g}$ of LPS. The present result for GLN effect is in line with other experiments using nutritional additives aimed to reduce postweaning diarrhea (SILVA et al., 2007; DALTO et al., 2011). The diarrhea episode is individual and leads to reduction of intestinal villi, and decreased enzymatic activity, digestibility and absorption of nutrients (RIOPEREZ et al., 1991; CERA et al., 1988; VENTE SPREEUWENBERG et al., 2003), accompanied by temporary immunosuppression which helps explain these results.

For housing conditions, however, AD pigs had a greater number of animals without diarrhea (Table 3 ) compared to INAD pigs (12 vs 4, respectively; $\mathrm{P}<0.05)$. Considering slight and severe diarrhea, AD pigs had a higher incidence of slight ( 9 vs 8 , respectively) and lower incidence of severe (3 vs 12 , respectively; $\mathrm{P}<0.05$ ) diarrhea compared to INAD pigs. Silva et al. (1999) studied the eco-pathology of post-weaning diarrhea and reported that a small area of space and feeder space per pig are among the factors most related with post-weaning diarrhea. In the present study, both housing conditions met the recommendation for these variables, however, drinker height, maximum flow rate, and floor type may have contributed to the higher incidence of diarrhea in INAD animals. The lower drinking efficiency, non-adjustable $90^{\circ}$ angle drinkers placed at a height of $37.5 \mathrm{~cm}$ off the floor increased the waste of water. Silva et al. (1999) reported that low water intake efficiency was related to the incidence of diarrhea. In addition, the high waste of water increased the humidity of the solid concrete flooring pens which were half covered with wood shavings, and according to Madec and Josse (1983), high humidity in the pens is related to multifactorial diseases such as diarrhea.

Table 3. Number of piglets that had diarrhea in two different housing conditions.

\begin{tabular}{|c|c|c|c|}
\hline \multirow[b]{2}{*}{ Degree of presentation } & \multicolumn{2}{|c|}{ Housing conditions } & \multirow[b]{2}{*}{ Total } \\
\hline & Nursery I & Nursery II & \\
\hline Without diarrhea (0 days) & $12 \mathrm{a}$ & $4 \mathrm{~b}$ & 16 \\
\hline Little diarrhea (1-3 days) & $9 b$ & $8^{\mathrm{a}}$ & 17 \\
\hline Significant diarrhea ( $>4$ days) & $3 b$ & $12 \mathrm{a}$ & 15 \\
\hline Total & 24 & 24 & 48 \\
\hline
\end{tabular}

Means followed by different letters in the line differ by chi-square test $5 \%$. Nursery I: slatted plastic flooring pens; Nursery II: solid concrete flooring pens.

\section{Conclusion}

Dietary supplementation with GLN didn't enhance growth performance during the 28 days post-weaning in pigs; however, when housing conditions were adequate, increased levels of GLN improved the efficiency of feed utilization. 
Adequate housing conditions (AD facilities) presented better results than INAD facilities, indicating that simple management and environment factors may produce remarkable results in terms of growth performance and incidence of diarrhea after weaning.

The standardization of nursery facilities using information already available in the literature may aid in reducing infection pressure, improving growth performance, and possibly potentiating the effects of nutritional additives as shown in the present study.

\section{Acknowledgements}

This study was supported by Ajinomoto do Brasil Ind. e Com. de Alimentos Ltda., São Paulo, Brazil; Fundação de Amparo à Pesquisa do Estado de Mato Grosso - Brazil (FAPEMAT); and Coordenação de Aperfeiçoamento de Pessoal de Nível Superior (CAPES).

\section{References}

CABRERA, R. A.; USRY, J. L.; ARRELLANO, C.; NOGUEIRA, E. T.; KUTSCHENKO, M.; MOESER, A. J.; ODLE, J. Effects of creep feeding and supplemental glutamine or glutamine plus glutamate (Aminogut) on pre- and post-weaning growth performance and intestinal health of piglets. Journal of Animal Science and Biotechnology, London, v. 4, n. 1, p. 1-12, 2013.

CERA, K. R.; MAHAN, D. C.; CROSS, R. F.; REINHART, G. A.; WHITMOYER, R. E. Effect of age, weaning and post-weaning diet on small intestinal growth and jejunal morphology in young swine. Journal of Animal Science, Champaign, v. 66, n. 2 p. 574-584, 1988.

DALLACOSTA, O.A.; MORES, N.; SOBESTIANSKY, J.; PERDOMO, C. C.; BARIONI JUNIOR, W.; GUZZO, R.; COIMBRA, J. B. S.; AMARAL, A. L. Caracterização do sistema hidráulico e da qualidade da água em granjas de suínos da região sul do Brasil nas fases creche, crescimento e terminação. Concórdia: EMBRAPA-CNPSA, 2000. 5 p. (Comunicado técnico, 247).
DALTO, D. B.; SILVA, C. A.; BRIDI, A. M.; GAVIOLI, D. F.; OLIVEIRA, E. R.; SILVA, R. A. M.; TARSIATO, A. A.; ALTMANN, A. H. S.; BRAZ, D. B.; KOBAYASHI, R. K. T.; VENÂNCIO, E. J. Plasma sanguíneo desidratado na recuperação de leitões leves ao desmame: desempenho zootécnico, perfil hematológico, freqüência de diarréia e viabilidade econômica. Semina: Ciências Agrárias, Londrina, v. 32, n. 4, p. 1989-2000, 2011. Suplemento 1.

DYBKJAER, L.; JACOBSEN, A. P.; TØGERSEN, F. A.; POULSEN, H. D. Eating and drinking of newly weaned piglets: effects of individual characteristic, social mixing, and addition of extra zinc to the feed. Journal Animal Science, Champaign, v. 84, n.3, p. 702-711, 2006.

FERREIRA, E. B.; CAVALCANTI, P. P.; NOGUEIRA, D. A. Experimental designs package. Rio de Janeiro, 2011. Available at: <http://cran.r-project.org/web/ packages/ExpDes/ExpDes.pdf $>$. Accessed at: 15 june 2012.

GARCÍA-HERRERA， J.; MARCA， M. C.; BROTLAROCHE, E.; GUILLÉN, N.; ACIN, S.; NAVARRO, M. A.; OSADA, J.; RODRIGUEZ-YOLDI, M. J. Protein kinases, TNF- $\alpha$, and proteasome contribute in the inhibition of fructose intestinal transport by sepsis in vivo. American Journal of Physiology - Gastrointestinal and Liver Physiology, Bethesda, v. 294, n. 1, p. 155-164, 2008.

JIANG, Z. Y.; SUN, L. H.; MA, X. Y.; ZHENG, C. T.; ZHOU, G. L.; CHEN, F.; ZOU, S. T. Effects of dietary glycyl-glutamine on growth performance, small intestinal integrity, and immune responses of weaning piglets challenged with lipopolysaccharide. Journal of Animal Science, Champaign, v. 87, n. 12, p. 4050-4056, 2009.

LOZANO, A. P.; POVEDA-PARRA, A. R.; SILVA, C. A.; SANTOS, A.; VENÂNCIO, E. J.; ARANTES, V.; NOGUEIRA, E. Effect of L-glutamine levels in piglets diets challenged with Escherichia coli lipopolysacharides. MVZ Córdoba, Córdoba, v. 19, n. 3, p. 4328-4337, 2014.

MADEC, F.; JOSSE, J. Influence of environmental factors on the onset of digestive disorder of the weaned piglets. Annales de Recherches Veterinaires, Paris, v. 14, n.4, p. 456-462, 1983.

MORES, N.; SOBESTIANSKY, J.; DALLA COSTA, O. A.; BARIONI JUNIOR, W.; PEDROSO DE PAIVA, D.; LIMA, G. J. M. M.; PERDOMO, C. C.; AMARAL, A. L.; COIMBRA, J. B. S. Fatores de risco associados aos problemas dos leitões no periodo pósdesmame. Concórdia: EMBRAPA-CNPSA, 1998. 12 p. (Comunicado técnico, 226). 
PARRA, J. S.; AGUDELO, J. T.; SANIN, D. P.; FORERO, J. D.; MUSKUS, C. L.; LOPEZ HERRERA, A. Intestinal expression of pro-inflammatory cytokines induced by oral intake of lipopolysaccharide (LPS) from E. coli in weaned pig. Revista Colombiana de Ciencias Pecuarias, Medellín, v. 26, n. 2, p. 108-118, 2013.

RIOPEREZ, J.; SANCHEZ, C. P.; CANTAÑO, M. Estudio histopatologico del ileon de lechones precozmente destetados dependiente del cereal utilizado en su alimentación. Archivos de Zootecnia, Córdoba, v. 40, p. 261-271, 1991.

ROSTAGNO, H. S. ; ALBINO, L. F. T.; DONZELE, J. L.; GOMES, P. C.; OLIVEIRA, R. F.; LOPES, D. C.; FERREIRA, A. S.; BARRETO, S. L. T.; EUCLIDES, R. F. Tabelas brasileiras para aves e suínos: composição de alimentos e exigências nutricionais. 3. ed. Viçosa, MG: Universidade Federal de Viçosa, 2011. 252 p.

SILVA, C. A.; BRIDI, A. M.; AGOSTINI, P. S.; VINOKUROVAS, S. L.; AGUSTO, R. M. N. Avaliação de complexo polivitamínico, polimineral, com aminoácidos, para leitões lactentes e recém desmamados: efeitos no desempenho, taxa de sobrevivência e índice de diarréia. Semina: Ciências Agrárias, Londrina, v. 28, n.2, p. 323-332, 2007.
SILVA, C. A.; BRITO, B. G.; MORES, N.; AMARAL, A. L. Ecopatologia da diarréia pós-desmame em granjas de suínos da região norte do Paraná. Ciência Rural, Santa Maria, v. 29, n.1, p. 39-43, 1999.

STOJANAC, N.; STEVANČEVIĆ, O.; POTKONJAK, A.; SAVIĆ, B.; STANČIĆ, I.; VRAČAR, V. The impact of space allowance on productivity performance and Salmonella spp. shedding in nursery pigs. Livestock Science, Miles, v. 164, p. 149-153, 2014.

VENTE SPREEUWENBERG, M. A. M.; VERDNOK, J. M. A.; BEYNEN, A. C.; VERSTEGEN, M. W. A. Interrelationships between gut morphology and feces consistency in newly-weaned piglets. Journal of Animal Science, Champaign, v. 77, n.1, p. 85-94, 2003.

WU, G.; BAZER, F. W.; JOHNSON, G. A.; KNABE, D. A.; BURGHARDT, R. C.; SPENCER, T. E.; LI, L. X.; WANG, J. J. Triennial growth symposium: important roles for l-glutamine in swine nutrition and production. Journal of Animal Science, Champaign, v. 89, n. 7, p. 2017-2030, 2011.

YI, G. F.; CARROL, J. A.; ALLEE, G. L.; GAINES, A. M.; KENDALL, D. C.; URSY, J. L.; TORIDE, Y.; IZURU, S. Effect of glutamine and spray-dried plasma on growth performance, small intestinal morphology, and immune responses of Escherichia coli K88+-challenged weaned pigs. Journal of Animal Science, Champaign, v. 83, n. 3, p. 634-643, 2005. 